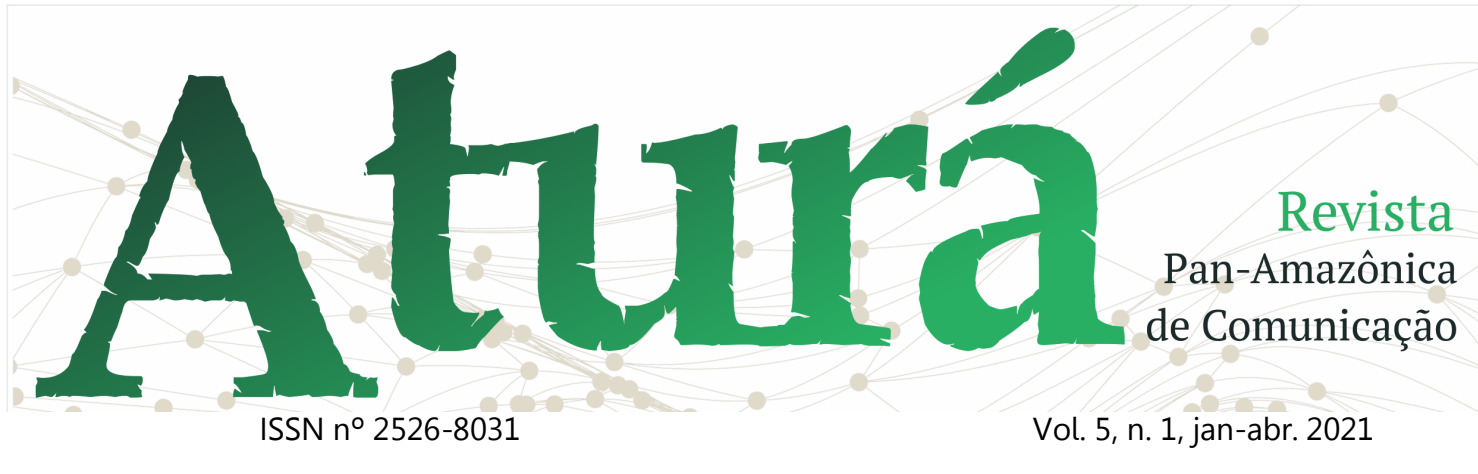

\title{
A ESTÉTICA DE FLUXO E A FICÇÃO CIENTÍFICA: REIMAGINANDO A EXPERIÊNCIA DO TEMPO EM UM NOVO REGIME DE HISTORICIDADE ${ }^{1}$
}

Aesthetics of Flow and Science Fiction: Reimagining the Experience of Time in a New Regime of Historicity

Estética del flujo y ciencia ficción: reimaginar la experiencia del tiempo en un nuevo régimen de historicidad

Lúcio Reis Filho, Universidade Anhembi Morumbi ${ }^{2}$

Marília Xavier de Lima, Universidade Anhembi Morumbi ${ }^{3}$

\section{RESUMO}

Nos últimos anos, produções de ficção científica contemporâneas parecem aderir a um estilo que prioriza o fluxo de sensações de imagens e som mais do que a narrativa. Nesse sentido, a presente proposta relaciona filmes de ficção científica contemporâneos à chamada estética do fluxo. Conforme veremos, Under the Skin (2014), High Life (2018) and Annihilation (2018) podem ser relacionados a essa estética, estilo de realismo cinematográfico dos anos 2000 que resulta de um novo regime de historicidade, caracterizado pela aceleração e alargamento do presente, e de novas abordagens no campo das humanidades, mais preocupadas com a vida cotidiana e o mundo ordinário. Em sua relação com o realismo tradicional e o gênero da ficção científica, esse realismo é marcado por uma atmosfera de desdramatização e rarefação, sem personagens definidos. Como será observado, tais filmes propõem uma gama de futuros possíveis a partir da nossa experiência contemporânea de tempo, resultado de esforços do mundo real para reimaginar e redefinir essa experiência.

\footnotetext{
${ }^{1}$ Trabalho apresentado em outubro de 2020 no GT História das Mídias Audiovisuais, sob coordenação de Tarcisio Oliveira (UFRR), no VI Encontro Regional Norte de História da Mídia.

${ }^{2}$ Doutor em Comunicação pela UAM, onde participa de grupos de pesquisa em cinema e audiovisual; e-mail: lucioreisfilho@gmail.com.

${ }^{3}$ Doutoranda em Comunicação pela UAM e professora de cinema na UFJF; e-mail: mariliaxlima@gmail.com
} 


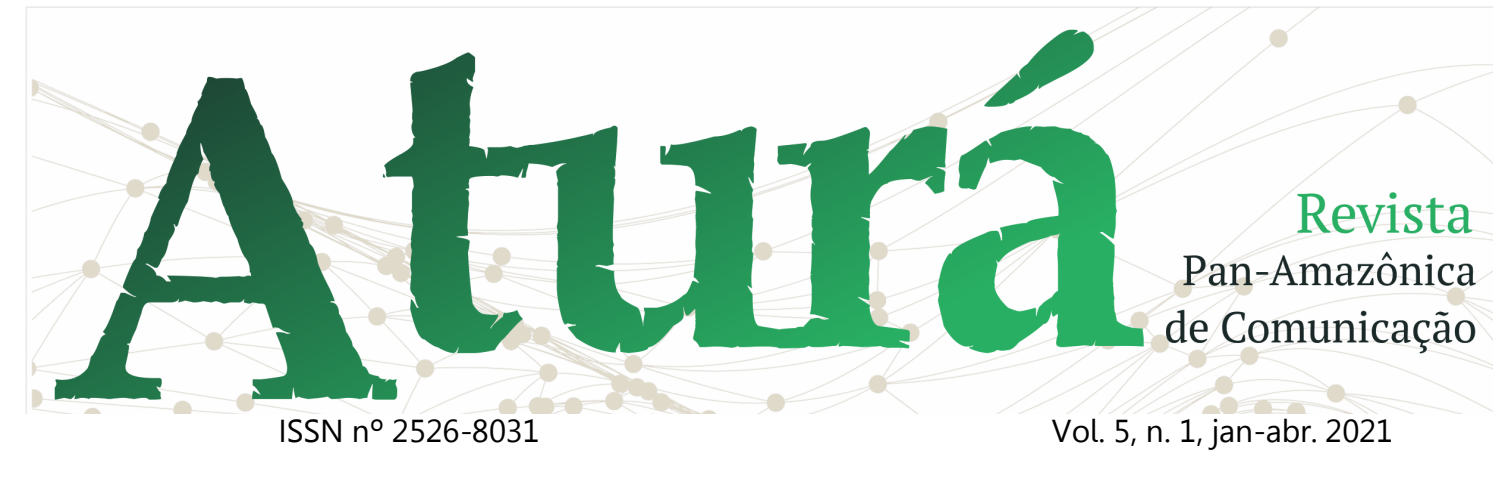

PALAVRAS-CHAVE: cinema e história; cinema de fluxo; ficção científica.

\begin{abstract}
In recent years, contemporary science fiction productions seem to adhere to a style that prioritizes not the narrative, but the flow of sensations rendered by image and sound. In this sense, this proposal intends to relate contemporary science fiction films to the socalled flow aesthetics. As we propose, Under the Skin (2014), High Life (2018) and Annihilation (2018) can be related to such aesthetic, a style of cinematic realism from the 2000 s that arises from a new regime of historicity, characterized by the acceleration and expansion of the present, and new approaches in the field of the humanities, more concerned with everyday life and the ordinary world. In its relationship with traditional realism and the science fiction genre, this realism is marked by an atmosphere of dedramatization and rarefaction, with no defined characters. As will be noted, such films propose a range of possible futures based on our contemporary experience of time, the result of real-world efforts to reimagine and redefine the experience.
\end{abstract}

KEYWORDS: cinema and history; aesthetics of flow; science fiction.

\title{
RESUMEN
}

En los últimos años, las producciones de ciencia ficción contemporáneas parecen adherirse a un estilo que prioriza el flujo de sensaciones de las imágenes y el sonido más que la narrativa. En este sentido, la presente propuesta relaciona el cine de ciencia ficción contemporáneo con la llamada estética del flujo. Como veremos, Under the Skin (2014), High Life (2018) y Annihilation (2018) pueden relacionarse con esta estética, un estilo de realismo cinematográfico de los años 2000 que resulta de un nuevo régimen de historicidad, caracterizado por la aceleración y ampliación del presente, y de nuevos enfoques en el campo de las humanidades, más preocupados por la vida cotidiana y el mundo ordinario. En su relación con el realismo tradicional y el género de la ciencia ficción, este realismo está marcado por una atmósfera de desdramatización y rarefacción, sin personajes definidos. Como se observará, estas películas proponen una serie de futuros posibles a partir de nuestra experiencia contemporánea del tiempo, resultado de los esfuerzos del mundo real por reimaginar y redefinir esta experiencia.

PALABRAS CLAVE: cine e historia; cine de flujo; ciencia ficción 


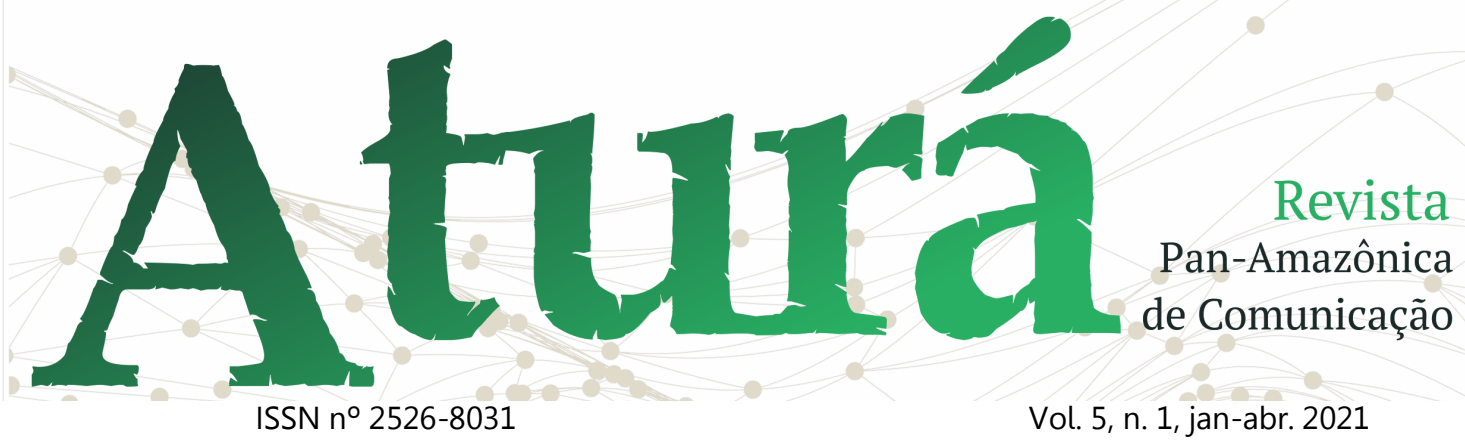

\section{Introdução}

O presente trabalho surgiu de uma pesquisa no campo das relações entre o Cinema e a História, dedicada a pensar as novas formas cinematográficas que emergem do modo pelo qual experimentamos $\mathrm{o}$ tempo na contemporaneidade. Observamos, portanto, como o chamado "cinema de fluxo" resulta de nossa experiência contemporânea do tempo e do advento de um novo "regime de historicidade", conceito utilizado por François Hartog (2015) para definir tanto um recorte quanto uma ferramenta do historiador.

Dado que o cinema incorpora formas narrativas e estéticas de seu tempo, e os gêneros cinematográficos articulam nossa experiência do tempo a novas combinações estéticas, notamos que certas produções contemporâneas de ficção científica aderem à estética de fluxo. Em Sob a Pele (Under the Skin, dir. Jonathan Glazer, 2014), uma extraterrestre "veste" um corpo humano feminino para seduzir homens e devorá-los em um espaço extradimensional sombrio, uma dimensão dissociada do tempo e do espaço. As cenas nesse ambiente contrapõem-se às demais, que são menos dramáticas e mais realistas. Por sua vez, a fotografia saturada de High Life (dir. Claire Denis, 2018), formada por planos longos, associa-se a uma narrativa rarefeita, focando na dimensão sensorial da imagem e do som. As cores são igualmente marcantes em Aniquilação (Annihilation, dir. Alex Garland, 2018). Enfim, veremos como esses filmes, caracterizados por uma atmosfera de desdramatização, aderem a um estilo que prioriza o fluxo de sensações de imagens e som, mais do que a narrativa.

\section{A estética de fluxo}

A noção de estética de fluxo surge, inicialmente, em um texto do crítico francês Stéphane Bouquet ("Plano contra Fluxo", publicado pela Cahiers du Cinéma em 2002), que faz uma distinção entre os cineastas do plano e os do fluxo. Os primeiros estão interessados no poder de construção de sentidos através da imagem, em uma forma de montagem e 


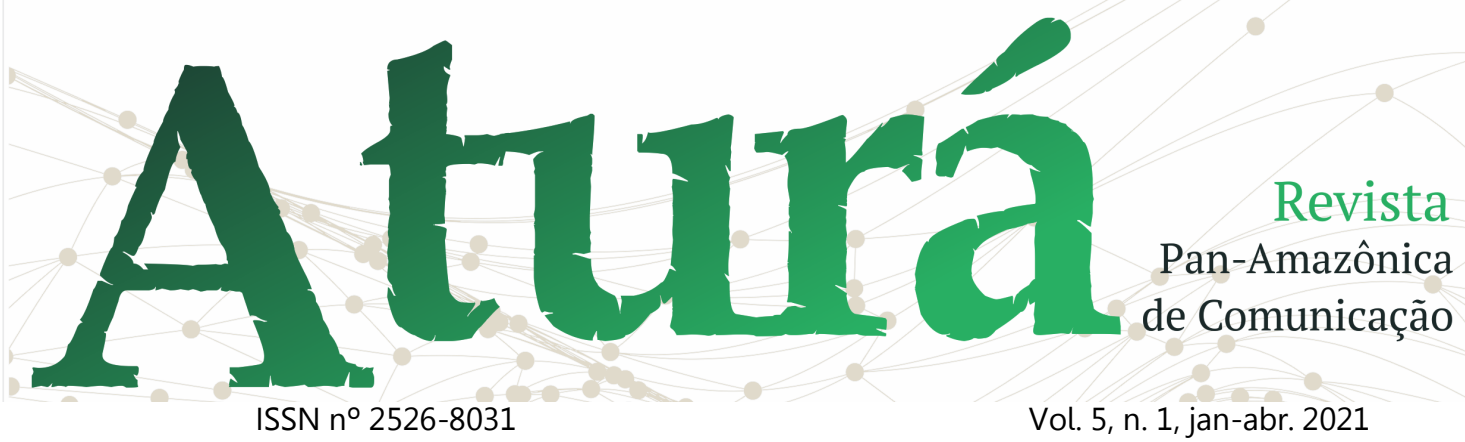

decupagem feita tijolo-a-tijolo (exemplificado por ele nos filmes de François Ozon). Os de fluxo, por outro lado, voltam-se para a imagem como sensação pura, menos para o discurso, criando histórias sobre nada, filmando não as ações ou conflitos dos personagens, mas afetos. Luiz Carlos Oliveira Júnior (2014), em seu trabalho sobre a mise em scène (ou ausência dela) no cinema contemporâneo define a estética do fluxo trabalhando:

Prioritariamente com sensações puras, com atmosferas, com a hipnose da experiência bruta dos significantes materiais (a luz, as cores, o som, a duração, os corpos em movimento), com a possibilidade de o cinema poder ser encarado, acima de tudo, como uma intensificação do olhar para o mundo (OLIVEIRA JÚNIOR, 2014, p. 9).

Para os críticos Bouquet (2002) e Martin (2012), nessa forma de se fazer cinema ocorre uma desdramatização, uma rarefação da narrativa, um modo de encenação que não apresenta conflitos, buscas, modulações, tampouco personagens. Assim, busca-se mais criar atmosferas e ambientações do que necessariamente contar uma história com

começo, meio e fim. No cinema contemporâneo, podemos observar essa tendência na obra de diretores de diversas partes do mundo, como Claire Denis (França), Pedro Costa (Portugal), Lucrecia Martel (Argentina), Gus Van Sant (Estados Unidos), Tsai Ming-Liang (Twain), Apichatpong Weerasethakul (Tailândia), Hou Hsia-Hsien (China), Jia Zhanke (China), entre outros.

Se o cinema de fluxo é promovido por sua dimensão sensorial, o corpo se torna o foco de atenção dessa experiência. Não apenas o corpo do espectador é convocado a participar do filme, como também um modo de trabalhar a câmera que transita entre os corpos dos personagens nos espaços, intensificando sua presença nas cenas. É nesse sentido que Erly Vieira (2014) discute uma espécie de câmera-corpo a partir da visualidade háptica de Laura Marks. A maneira de filmar no filmes de fluxo que o pesquisador análise permite uma contato com a imagem que beira uma dimensão tátil. $\mathrm{O}$ uso, por exemplo, de planos detalhes e próximos dos 


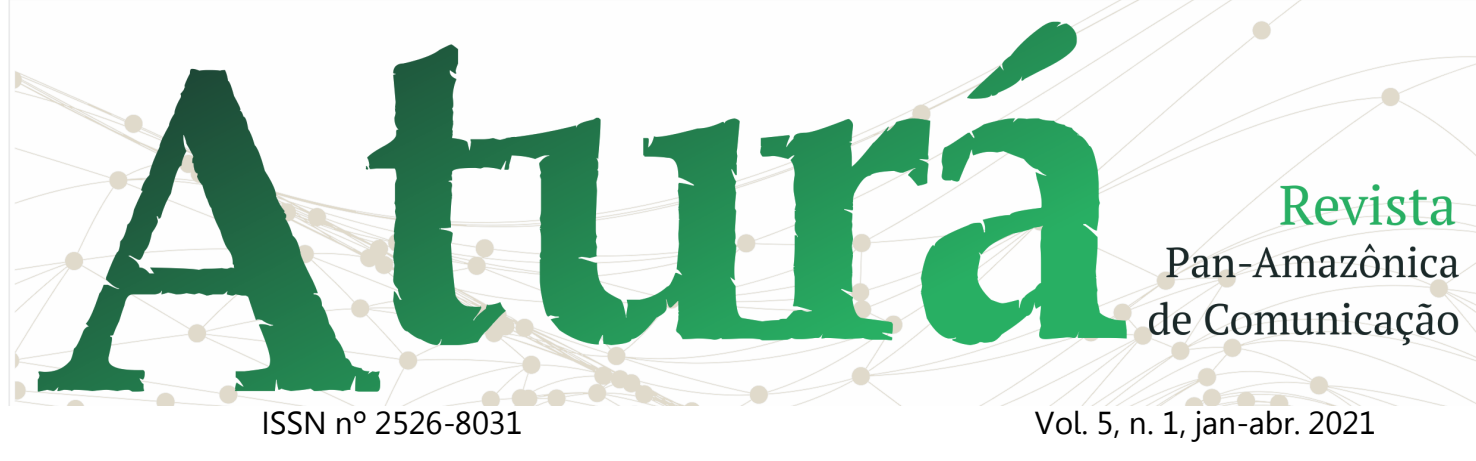

objetos filmados potencializa um chamado ao uso da memória corporal do espectador para preencher o espaço aberto pelo recorte feito no enquadramento. Segundo Vieira (2014, p. 1223), "nesse tipo de visualidade, as imagens percebidas são completadas justamente pela convocação da memória e da imaginação, de modo a conferir outros significados ao que se filma em plano-detalhe, para além de explicações racionais".

\section{A experiência contemporânea do tempo}

Como relacionar a estética de fluxo ao contexto atual? Sabe-se que o cinema incorpora o tempo em seu processo de criação e produção, seja através da tecnologia, ${ }^{4}$ do tema ou da forma fílmica. Se aplicarmos a noção de "regime de historicidade" (HARTOG, 2015) como instrumento de análise, podemos observar como são concebidos

4 Segundo Eric Hobsbawm (2013), o que caracteriza as artes em nosso século é sua dependência com a revolução tecnológica, única do ponto de vista histórico, e sua transformação por ela, em particular no tocante às tecnologias de comunicação e reprodução.

e vivenciados o passado, o presente e o futuro, que "formam um continuum indivisível" (HOBSBAWM, 2013, p. 27). Para Hartog, o conceito de historicidade remete a uma longa história filosófica e expressa "a forma da condição histórica, a maneira como um indivíduo ou uma coletividade se instaura e se desenvolve no tempo." (2015, p. 12). O regime de historicidade, por sua vez, é construído pelos historiadores como ferramenta que ajuda a melhor apreender momentos de crise do tempo; ou seja, é uma forma de engrenar passado, presente e futuro (2015, p. 11 ; 12; 13; 37). A construção de regimes específicos estabelece diferentes conexões entre as temporalidades, determinantes para a escrita da história.

De sociedade a outra, e de tempo em tempo, variam os modos de historicidade, isto é, "as maneiras de viver e de pensar essa historicidade e de servirse dela, os modos de articular passado, presente e futuro: seus regimes de historicidade" (HARTOG, 2015, p. 45). Atualmente, a maneira como experimentamos o tempo se dá na forma 


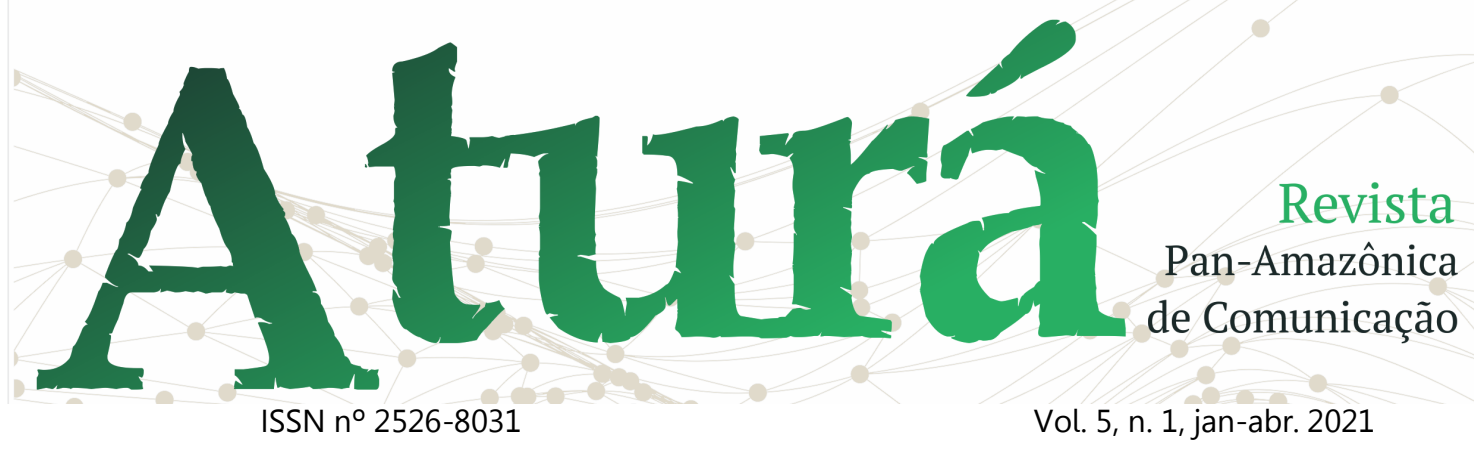

de um "presentismo", definição de Hartog para a experiência contemporânea do tempo, dado o rápido alargamento da categoria do presente - que se tornou de certo modo perpétuo, inacessível e quase imóvel, ou mesmo onipresente. Nas suas palavras, "tudo se passa como se não houvesse nada mais do que o presente" (2015, p. 39-40). Daí emerge um novo regime de historicidade, ao qual está relacionada a progressiva aceleração do tempo histórico.

\section{A dimensão sensível da imagem e do som em High Life}

Em High Life (2018), a diretora francesa Claire Denis trabalha pela primeira $v e z^{5}$ com a ficção científica. Embora se distancie tematicamente de suas produções anteriores, como Bom trabalho (Beau travail, 2000), Deixe a luz entrar (Un beau soleil intérieur, 2017), Nenette e Boni (Nénette et Boni, 1996) e Bastardos (Les salauds, 2013), seu modo de filmar permanece preocupado em oferecer uma experiência espectatorial

\footnotetext{
${ }^{5}$ É também seu primeiro filme falado em inglês.
}

mais calcada na dimensão sensível da imagem e do som do que, propriamente, nos cursos da narrativa.

No filme, um grupo de condenados foi incubido da missão de encontrar uma fonte de energia em buracos negros. O longa é centrado nos personagens Monte (Robert Pattinson) e Doutora Dibs (Juliette Binoche). Monte é um pai solteiro; ele é mostrado do início do filme com uma criança, Willow. Descobrimos depois que a menina nasceu dentro da nave em decorrência das experiências de fertilidade da Doutora Dibs. Ela, por sua vez, é a personagem mais excêntrica do filme, com um misto de genialidade $e$ insanidade que beira a caracterização de outros personagens conhecidos do cinema, como o personagem-título de $D r$. Mabuse, o Jogador (Dr. Mabuse, der Spieler, dir. Fritz Lang, 1922) e Hal de 2001: Uma Odisséia no Espaço (2001: A Space Odyssey, dir. Stanley Kubrick, 1968). A médica foi condenada por suas experiências com a reprodução humana; na nave, ela faz dos detentos cobaias 


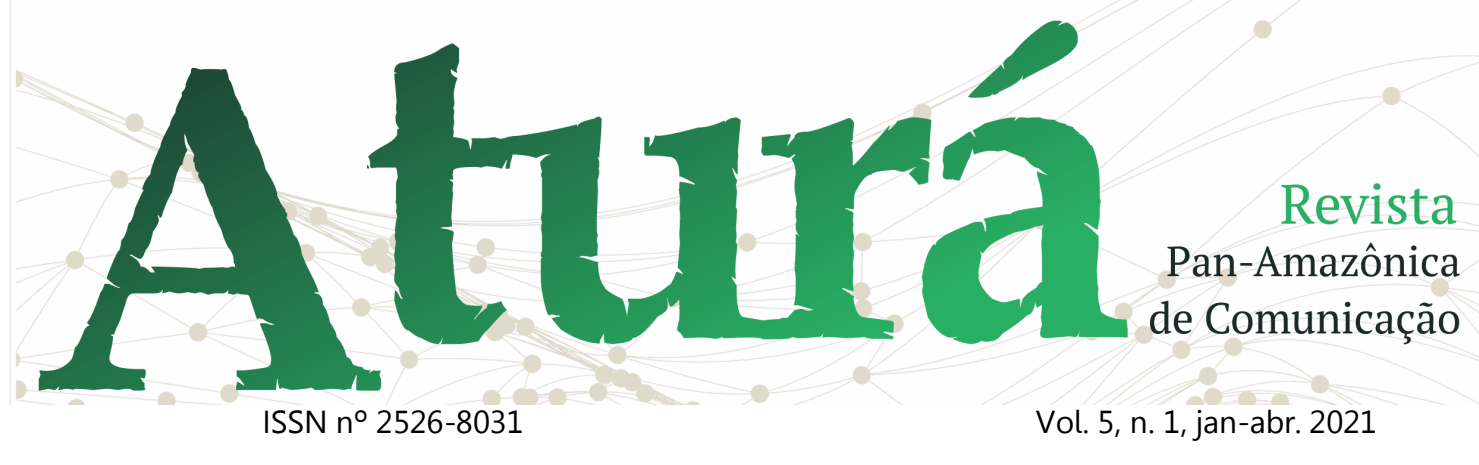

para seus experimentos em condições limítrofes.

Na nave, há uma estranha máquina chamada de "A Caixa", único lugar onde os personagens podem se masturbar. Aqui, a narrativa encontra sua vocação mais sensorial, proporcionando os momentos mais intensos de artificialidade da imagem e do som no filme. Em um desses momentos, dentro da Caixa, a Dra Dibs simula uma espécie de brincadeira com entonação sexual como se estivesse em um touro mecânico. A cena, fragmentada em planos detalhes, mostra partes de seu corpo nu, intercalando com imagens da máquina. A mistura dos corpos enseja o entrelaçamento dos fluidos resultantes do exercício sexual entre seu corpo e a máquina, atingindo $O$ ápice do artificialismo cinematográfico. A cena conduz a um modo de experiência cinematográfica interessada em afetar mais do que proporcionar elementos importantes para a história do filme. A construção cênica deriva de ambientação fotográfica baseada em luzes artificiais e trilha sonora repleta de ruídos não diegéticos. Os elementos, portanto, potencializam os efeitos sinestésicos da experiência fílmica.

A cena mobiliza, desse modo, o encontro do artifício cinematográfico do fluxo das imagens e dos sons com as sensações. A montagem e a decupagem não operam uma ordenação voltada para o curso da narrativa; a cena se esgota nela mesma, como o próprio gozo da autoestimulação sexual representada ali. Observa-se que os filmes sob a chancela do "cinema de fluxo" buscam essa dimensão afetiva em detrimento das suas operações narrativas ligadas à história.

Porém, quanto ao modo de "afetar" o espectador, é importante ressaltar a distinção entre os filmes de fluxo e àqueles que seguem o padrão da linguagem cinematográfica clássica. No cinema clássico narrativo, os eventos narrados estão em função daquilo que a história demanda para o engajamento do espectador. Ou seja, apresentam um modo de experiência perceptiva e afetiva voltada para a narrativa. No cinema de 


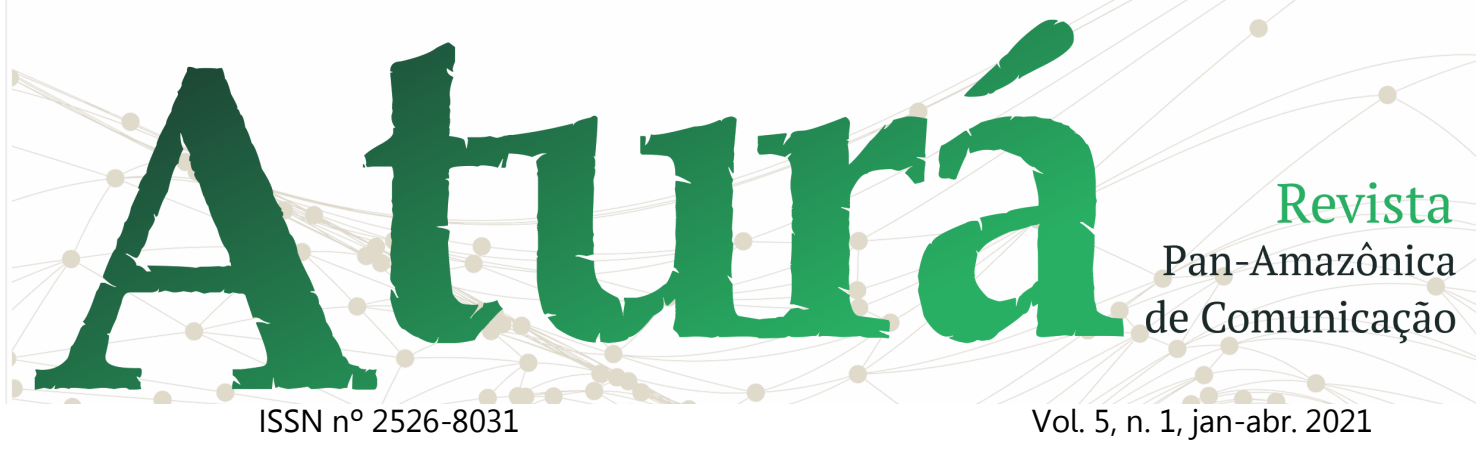

fluxo, por outro lado, a experiência afetiva se descola da história narrada por impossibilitar a relação entre aquilo que é mostrado com a sua finalidade para o todo do filme. Isto é, o plano, como apreendeu Bouquet, deixa de funcionar como um tijolo, unidade mínima da cena que acrescentaria um sentido e somaria informações para a construção de uma história. É justamente a desarticulação da enunciação entre seu conteúdo e seu entendimento que provoca uma experiência afetiva "difusa, multiforme, reticular e dispersiva" (VIEIRA JÚNIOR, 2014, p. 1221). Para Erly Vieira Júnior (2014), os afetos no cinema de fluxo:

Eclodiriam dentro do plano, não necessariamente atrelados ao cerne narrativo da cena. É como se compusessem um registro paralelo, capaz de tensionar nossa percepção do conjunto de simultâneos microeventos e microdeslocamentos corporais registrados pela câmera, construindo um espaço-tempo narrativo que concebe o cotidiano como uma experiência de sobrevalorização sensorial, a reverberar diretamente no corpo e nos sentidos do espectador (VIEIRA JÚNIOR, 2014, p. 1221).

Além disso, a montagem fragmenta a história dos personagens, desarticulando a linearidade do tempo. $\mathrm{O}$ filme começa mostrando Monte e Willow, pré-adolescente, sendo eles os únicos na nave. No decorrer da trama, entendemos que são os únicos sobreviventes de uma tripulação de condenados. Dessa forma, o espaço temporal da narrativa alude à própria maneira como o tempo é experimentado pelos personagens da nave, os quais vivem um cotidiano cuja única perspectiva é o encontro inevitável com o buraco negro. No final do filme, pai e filha concluem a missão ao chegar no buraco negro representado por um arco dourado. Eles atravessam o arco de mãos dadas e contemplam a vista. Por meio de uma montagem paralela, o filme sugere que eles saem da nave em direção ao brilho dourado, pois mostra os personagens em um primeiro plano já sem o capacete do traje espacial. Em seguida, um plano aberto mostra, sobre um fundo preto, uma fenda dourada retangular que se abre cobrindo o negrume com uma luz brilhante dourada.

$\mathrm{Na}$ relação como o presentismo, esse final expressa a aposta no progresso 


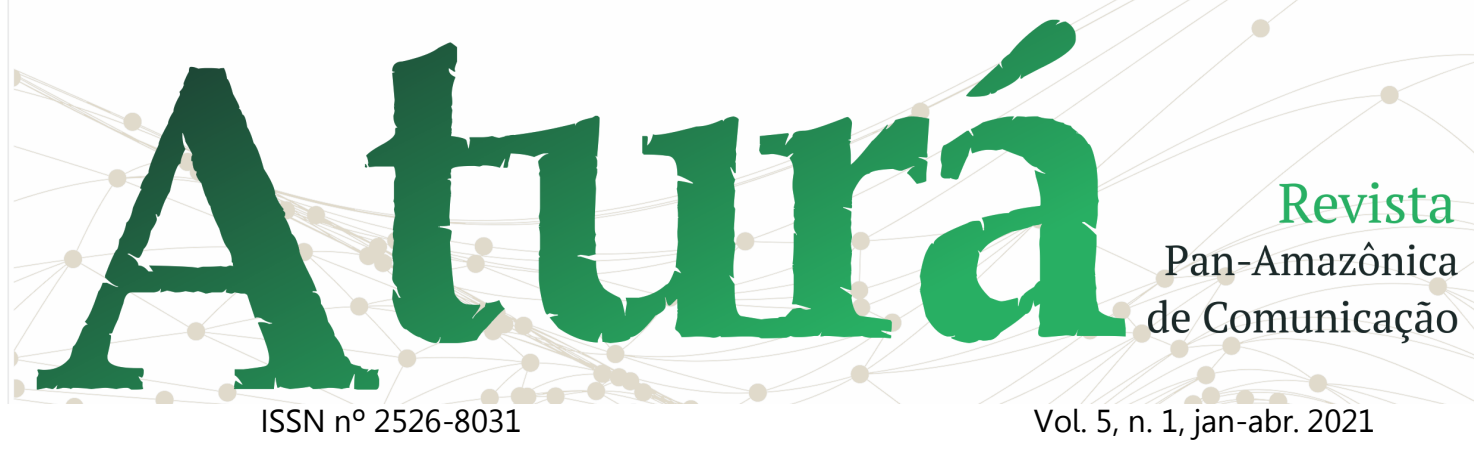

na missão de condenados que já não apresentam expectativa sobre o futuro. $O$ conceito moderno de história é fundado na noção de progresso. O que antes predominava era o futuro na esteira do novo ou voltado para certa finalidade. Mesmo após a Segunda Guerra Mundial, o "regime moderno de historicidade" continuou estabelecido em função das ações de reconstrução e de aceleração do desenvolvimento; no entanto, o olhar para o futuro perdeu espaço para o presente, como Hartog coloca:

[...] o Progresso se apresentava como
uma aceleração da aceleração
anterior. O "Futuro radioso"
socialista, o "Milagre alemão"
capitalista ou "Os Trinta Anos
gloriosos" da França foram os
destaques! De uma tal conjunção
pode-se, entretanto, constatar que o
futuro ocupava cada vez menos lugar
comparado ao presente, que cada
vez mais ganhava o primeiro plano: o
presente e nada além do presente
(HARTOG, 2015, p. 25).

A saída tecnológica para resolver os problemas relacionados às fontes de energia é destinada ironicamente àqueles que não apresentam uma perspectiva de futuro. O filme termina, portanto, aludindo ainda a um presente dos personagens e um futuro incerto. Segundo Eric Hobsbawm (2013), a "civilização burguesa europeia" desapareceu depois da Primeira Guerra, da qual jamais se recuperou. Nos anos 1960, quando o mundo sofreu uma grande transformação, as regras e convenções que governavam as relações humanas se desmancharam. $O$ progresso do capitalismo foi posto em xeque e, com ele, a própria noção de tempo como progresso. Inaugura-se uma cultura do consumo, em que tudo é transformado em produto; a sociedade do espetáculo e os simulacros midiáticos atingem o ápice.

\section{Sob a pele. o vazio e o estado de estranheza}

Em Sob a Pele (2014), de Jonathan Glazer, nota-se um modo de se trabalhar a imagem e som mais preocupado em criar experiência perceptivas e afetivas do que propriamente contar uma história. A personagem principal, interpretada pela atriz Scarlett Johansson, é uma extraterrestre que se alimenta de corpos humanos. 


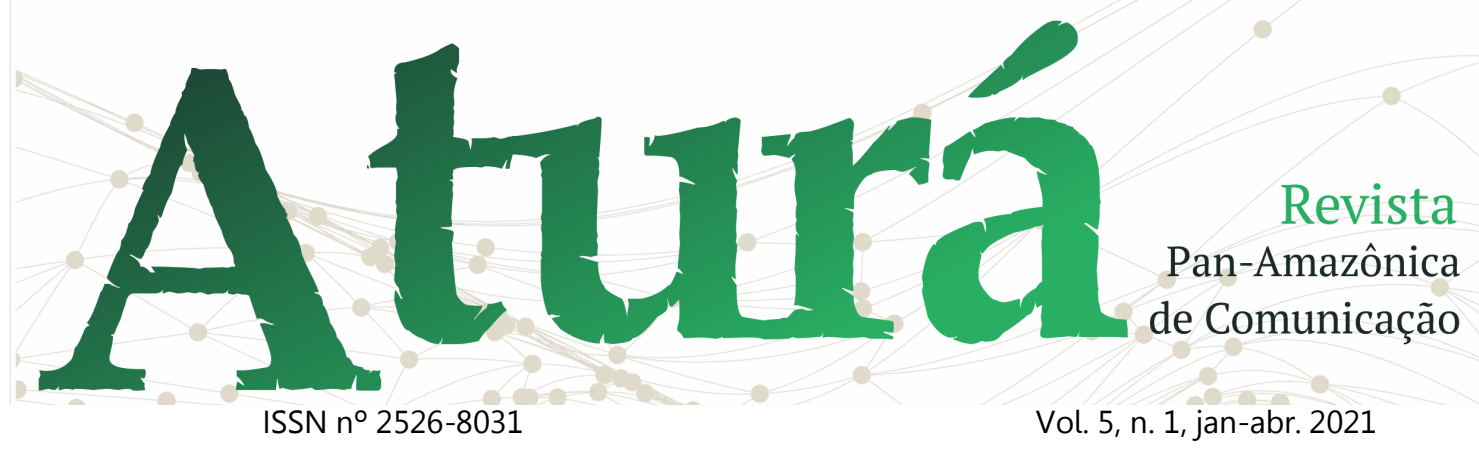

O filme começa com um plano em movimento, fechando o enquadramento em uma esfera luminosa em fundo preto que lembra um sol, mas que emite radiação azulada. A trilha sonora é uma música ruidosa no tom de violinos agudos. Em plano aberto, é mostrado o "sol" indo em direção ao fundo de uma outra grande esfera, que tem a sua frente o que parece ser uma lua. Ambos tiveram a "coroa" meramente delineada, não deixando visível a parte interna. Uma voz feminina ao fundo diz palavras em língua irreconhecível. Um ponto pequeno e luminoso passa no quadro em direção ao centro entrando por um buraco refletindo luz, ao entrar, a fenda se fecha.

Agora sobre um fundo branco, o plano ganha profundidade com algo que lembra uma xícara de café filmada em plongée absoluto. Nele há um pequeno ponto luminoso em movimento, em seguida, passa-se para um plano de um olho, onde também vemos o pequeno ponto luminoso. A voz continua a pronunciar palavras, agora reconhecíveis, mas que não chegam a criar uma síntese.
Apenas se assemelham foneticamente. $\mathrm{O}$ nome do filme aparece cortando a cena bruscamente.

\section{Detivemo-nos} mais detalhadamente nesta cena, pois apresenta elementos importantes para nossa proposta de analisar a dimensão sensorial desses filmes de ficção científica. De início, as imagens mostram apenas formas delineadas que sugerem ser o sol, a lua e a terra, as quais podem ser associadas ao espaço, sendo o ponto luminoso, que entra no quadro, a nave da personagem alienígena. Aqui, há um recurso mínimo em relação às informações imagéticas e sonoras, dando-nos apenas alguns elementos que nos permite uma associação. Logo, a cena chama atenção para a sua própria forma, mais do que para aquilo que representa, pois não temos informações suficientes da narrativa para entender seu conteúdo. Essa maneira de narrar, portanto, escancara o modo artificial pelo qual a imagem e o som são operados, gerando com isso um estado de estranheza. 


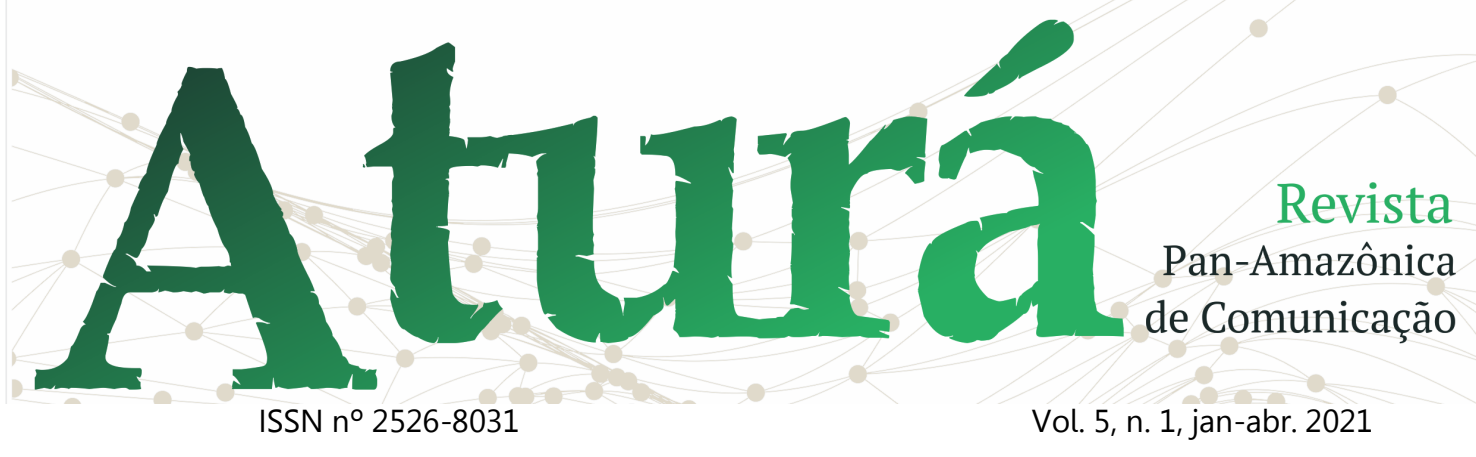

O filme mobiliza um narrador que mais sugere do que direciona os significados do filme. Aproximando-se da estética de fluxo - que potencializa mais a dimensão sensorial das imagens e do som do que seus elementos narrativos fundamentais para o entendimento da história -, ocorre "uma primazia do sensorial e do corpóreo em detrimento da psicologia e do discurso" (OLIVEIRA JR., 2014, p. 145). Assim, o cinema de fluxo volta seu interesse para o 'corpo' e para os afetos. Incorpora, fora dos padrões normativos, os seres e as paisagens.

Acompanhamos no filme a jornada da extraterrestre de capturar ou abduzir os seres humanos. Vestindo a pele de uma mulher, a personagem dirige pela cidade caçando suas vítimas, buscando principalmente os homens que the parecem presas mais fáceis. Ao encontrar um homem, ela o leva até uma casa cujo interior é completamente vazio, inclusive de luz. Apenas os personagens são iluminados. Esse espaço gera estranheza, pois aparentemente não há uma fonte de luz que justifique esse foco de luz nos personagens.

A alienígena, enquanto se despe, caminha em meio a uma imensidão preta aparentemente infinita, atraindo a presa que não percebe o quão estranho é o local e, menos ainda, o caminho que termina em uma substância líquida. Chegando ao centro, a vítima afunda até desaparecer. Não diálogos, nem som diegético, apenas ruídos e um trilha com sons agudos, criando uma tensão na cena. A ambientação vazia lembra um estúdio fotográfico no qual os personagens ficam centralizados no quadro. Dessa forma, a imagem cria mais um artifício que pouco contribui para entendimento principal do filme. Afinal, qual é o objetivo da alienígena? Por que ela captura os humanos?

Em outra cena, o filme nos mostra o que acontece com aqueles homens. Ao afundarem, eles ficam submersos, com a pele rugosa até seu corpo enrugar completamente, restando apenas a pele flutuando como um manto. Depois disso, é mostrado ainda sobre um fundo infinito 


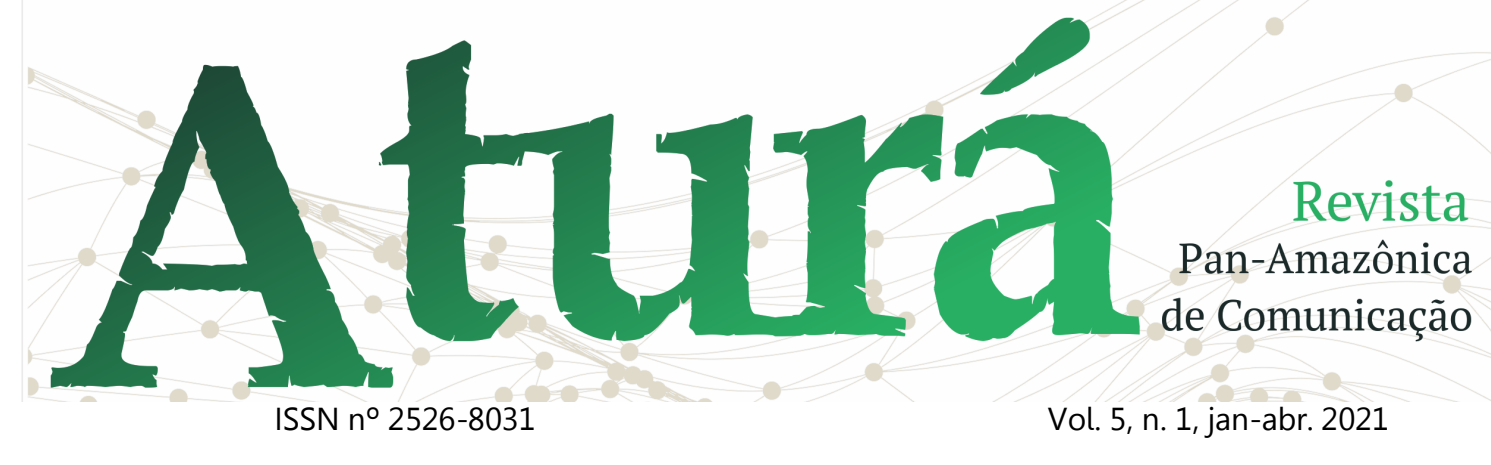

preto um rio de um líquido viscoso vermelho que corre até uma fenda retangular vermelha também. Quando o líquido acaba de escoar até o buraco, a cena muda para um plano com um quadro preto sendo cortado por uma linha vermelha; o próximo plano fica tremido e sobre um fundo agora vermelho mostra uma forma escura que parece molecular.

Em seguida, novamente sobre um fundo preto, um ponto luminoso branco emite uma luz rosa e roxa se transformando em outras cores até no seu centro mostra um forma pequena escura. Essa sequência nada nos informa diretamente sobre o que acontece com o corpo dos homens e o que é criado a partir disso. As formas geométricas em um ambiente minimalista, criadas com algumas cores primárias, novamente, nos sugere associações abrindo para mais lacunas do que explicações.

É interessante notar que essas formas geométricas lembram a estética do cinema puro e poético das vanguardas modernas dos anos 1920. Artistas como

Hans Richter ${ }^{6}$ propunham um tipo de cinema que fosse fiel às suas especificidades cinematográficas, ${ }^{7}$ atreladas à pureza das formas e dinâmicas da luz. Para ele, cada fotografia correspondia ao registro de uma imagem pictórica abstrata, suprimindo-a de qualquer vestígio mimético. Dessa forma, o interesse tanto do cinema puro, assim como do cinema do fluxo e deste filme, está em dar ao espectador uma percepção das imagens que sobreponha, à narrativa, sua dimensão sensorial. Nesse sentido, o filme atravessa a estética do fluxo na qual:

\begin{abstract}
Há um transbordamento do narrativo, uma vontade de algo que não seja só uma história (um sentido, uma emoção), mas que percuta no corpo, em 'estados pouco evidentes do corpo e da consciência', submergindo 0 espectador num 'banho de sensações novas' (OLIVEIRA JÚNIOR, p. 165).
\end{abstract}

Por fim, a alienígena foge de sua missão e de seu parceiro buscando

\footnotetext{
${ }^{6}$ Ver por exemplo o filme Filmstudie (1926) de Hans Richter.

${ }^{7}$ A favor de um cinema puro e poético através da objetividade da imagem fotográfica, como uma expressão não discursiva de algo. Fiéis então a pura sensação visual e às propriedades dinâmicas da luz.
} 


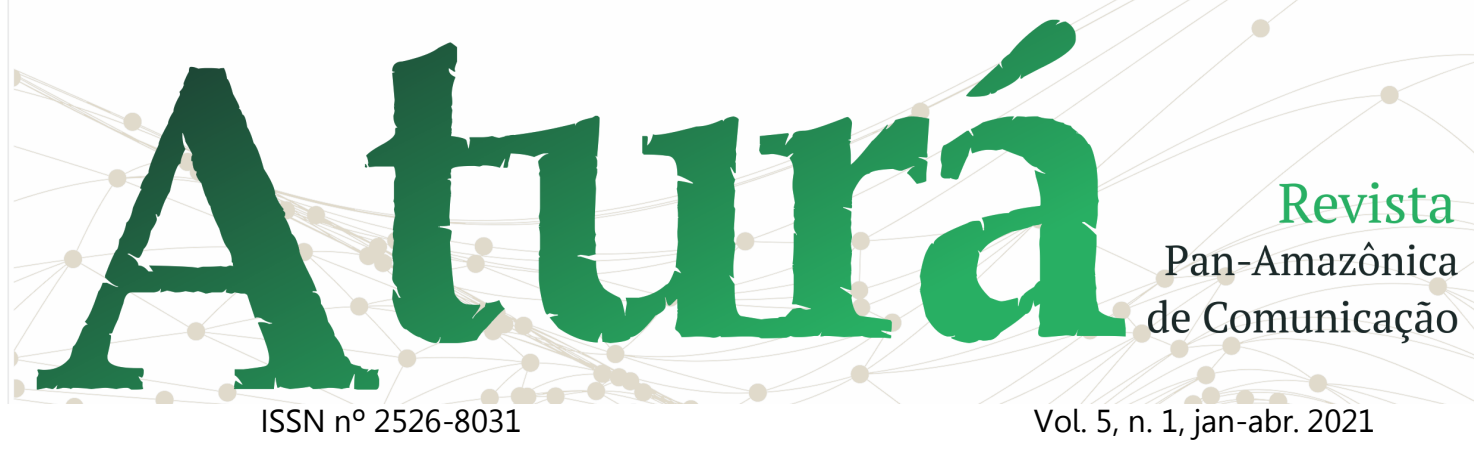

experienciar seu corpo. No entanto, consegue dar explicações lógicas sobre o escondida na floresta acaba sendo atacada por um homem que rasga sua pele revelando seu verdadeiro corpo; preto, com forma humana, porém sem olhos e boca. $O$ homem the incendeia $\mathrm{O}$ corpo.

\section{O avesso do mundo em Aniquilação}

Uma mesma desorientação temporal é criada pela montagem e também pela narrativa em Aniquilação (2018), de Alex Garland. O filme acompanha a busca da bióloga Lena (Natalie Portman) para entender o que houve com seu marido na estranha zona chamada de Área X. O local foi atingido por uma espécie de meteoro, que provocou diversas mudanças no meio ambiente à sua volta. A Área foi demarcada e isolada, com o acesso controlado pelo governo.

Seu marido Kane (Oscar Isaac), que estava desaparecido, volta misteriosamente para casa depois de doze meses. Uma lacuna na narrativa à qual Lena tenta preencher, Kane não

que the aconteceu; sua fala é lacunar, dando apenas sugestões a possíveis explicações. Seguindo a estrutura da narrativa clássica, Lena atende ao chamado da expedição para investigar o lugar, no entanto, ao invés de encontrar as explicações racionais para o evento, ela encontra um novo modo de existência, mais aberto às dimensões sensíveis dos afetos e menos lógico.

O que desencadearia em uma "jornada de heroína", na qual ela terminaria renovada, com uma lição aprendida depois de passar por diversos testes, Lena acaba sem entender o que houve, com apenas flash dos acontecimentos, tendo apenas seu corpo como peça fundamental para a conservação de sua memória.

Lena é a única sobrevivente da equipe de resgate, e o filme começa com uma cena de interrogatório sobre sua expedição. Dentro da Área, a sensação do tempo é distinta: a personagem sente que ficou apenas alguns dias no local, embora tenha ficado quatro meses. 


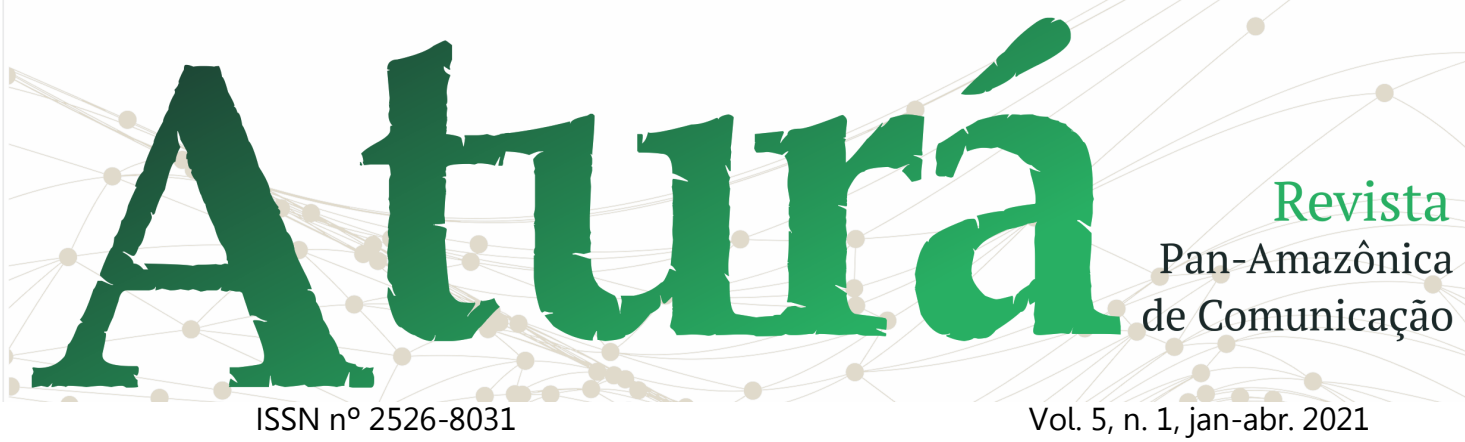

Confusa, sua memória não consegue acessar de forma clara e lógica a ordem dos acontecimentos, o que the vem à tona são fragmentos de memórias atravessados por sensações experimentados do outro lado.

A Área $X$ é chamada pelos personagens de "Brilho" pela luz que reflete no ambiente: uma mistura de tons brancos, amarelos, verdes e roxos. Pouco se sabe sobre $\mathrm{o}$ que aconteceu $\mathrm{e}$ acontece no local. Há apenas teorias que não são possíveis de serem provadas em virtude do fracasso das missões de expedição.

Nesse sentido, o nome se torna ideal para referenciar um espaço que apenas é visto e sentido. Logo, o que ela experimentou na Área foi um fluxo de sensações as quais ainda não havia vivenciado. Como bióloga, o local the parecia fora da ordem natural, pois ao longo do percurso na área ela encontrou várias anomalias genéticas na natureza, colocando em xeque seu próprio conhecimento, abrindo assim o espaço para o não-pensado, o nunca visto.

A passagem de tempo no local é fragmentada, fazendo com que as personagens ficam desorientadas sem saber quanto tempo estão ali. Aqui a montagem faz saltos entre uma cena e outra mostrando a descontinuidade entre as ações, abrindo assim espaço para as lacunas da narrativa.

O artifício é importante para criar uma desorientação também para o espectador que, junto com a equipe de expedição, fica à deriva na zona. Em uma de suas falas, Lena menciona que a experiência foi parecida com um sonho (ou pesadelo), pela deformação inexplicável dos seres na floresta, pelos saltos temporais e pela ausência de memória sobre os acontecimentos recentes. Como um sonho, era possível relacionar os elementos sem fechar o sentido dos eventos em uma única perspectiva, racional e lógica. Por fim, o lugar estranho desperta em Lena um estado de contemplação, de admiração por algo que nunca havia visto.

A aniquilação que nomeia o filme ilustra o próprio ambiente que vai cada 


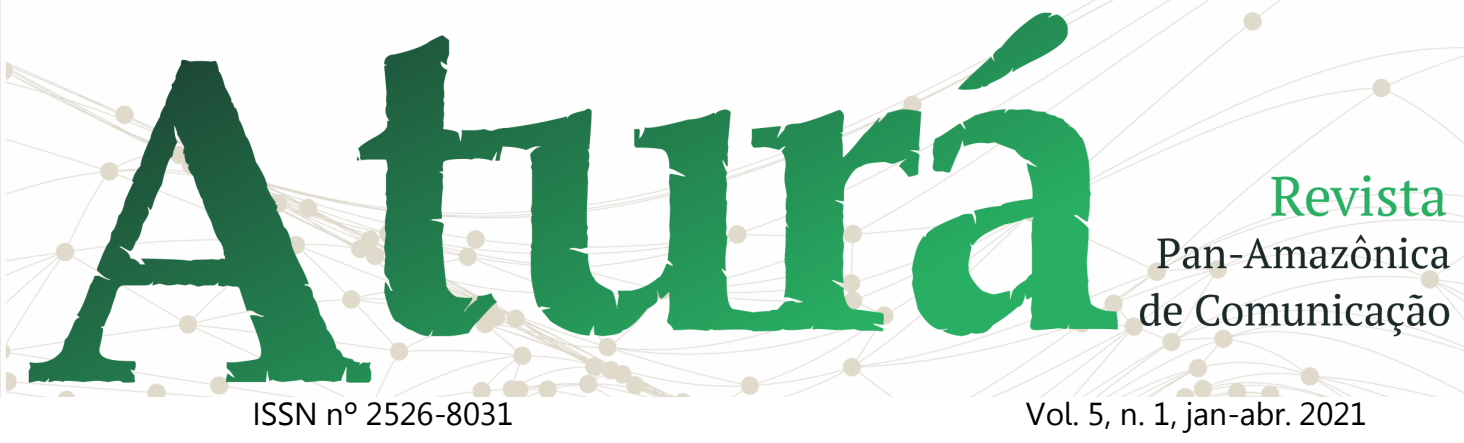

vez mais se autodestruindo, porém, dando lugar a novas formas de vidas a partir da metamorfose que hibridiza as diferentes espécies. Esse processo pode ser entendido como parte da proposta da ficção científica de lançar reflexões para o futuro dos seres humanos no contexto contemporâneo do multiculturalismo e da efemeridade.

Em Tempos fraturados (2013), Hobsbawm apresenta sua visão de uma sociedade que perdeu o rumo e que aguarda, desgovernada e desorientada, nos primeiros anos do novo milênio, um futuro irreconhecível. Este cenário parece resultar da superação do regime moderno de historicidade e do advento de um novo regime, o presentismo. Este processo foi marcado por momentos em que se questionou a expectativa de futuro - as duas guerras mundiais, o ano de 1968, a crise das identidades nacionais, o hiperconsumo, a globalização e o multiculturalismo. Com o presente ubíquo e onipotente, valoriza-se então o imediatismo.

A aniquilação pode ainda representar um ciclo que se fecha, dando lugar a algo novo. Uma das personagens, a Doutora Ventress (Jennifer Jason Leigh), que lidera o grupo de expedição, apresenta essa hipótese de que temos entranhado em nossas células o impulso da autodestruição. Pela maneira como os eventos são mostrados, é notável a forma como as espécies vão se transformando em algo novo, inominável ainda. Um modo então de sair de um estado estável, conhecido, fundamentado, para algo caótico, sem ordem ou hierarquia.

O objetivo da missão era chegar até o "Farol" onde o brilho se origina. Ao longo do percurso, elas descobrem que o "Brilho" age como um prisma que refrata o DNA de todos os seres vivos próximos a ele, criando mutações com novas sequências genéticas. Lena consegue chegar até o "Farol", lá encontra Ventress que, por sua vez, desintegra-se na frente de Lena. Uma luz brilhante sai de sua boca. Sua explosão deriva em pequenas partículas de luz que se assemelham a células. Seu corpo dá lugar a uma luz 


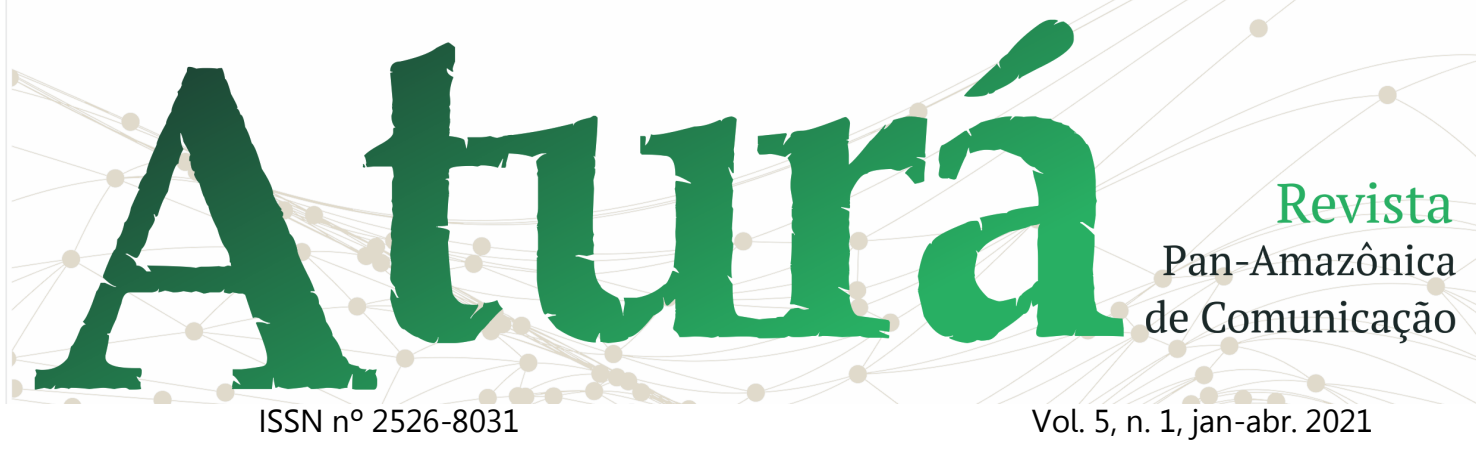

redonda que parece magnetizar as partículas. O lugar onde está é escuro, iluminado pela esfera brilhante com uma fumaça estranha e colorida ao seu redor, em constante movimento. A cena é repleta de elementos artificiais, que não têm equivalência na natureza. É válido ressaltar, aqui, a entrada de uma trilha sonora composta por tons eletrônicos, potencializando ainda mais a artificialidade da cena.

Como as partículas, Lena também é atraída pelo centro luminoso que reflete diversas cores e formatos, como um caleidoscópio colorido. Imagem e o som intensificam, pelo uso das cores, da luz, da trilha eletrônica, a dimensão sensorial da cena, mais do que propriamente seu teor narrativo para o entendimento da história. Os acontecimentos misteriosos gerados pelo "Brilho" ficam assim cada vez mais lacunares. Dessa forma, o filme ecoa um dos princípios da estética de fluxo que "se furta a qualquer princípio de identidade, de permanência, de lógica; ele admite o mundo como puro devir" (OLIVEIRA, p. 172).

A partir de uma gota de sangue de Lena, que respinga na esfera luminosa, surge um ser com um formato do corpo humano, sem gênero, com uma pele cintilante. $\mathrm{O}$ corpo estranho se movimenta mimetizando os gestos de Lena, como uma cópia dela. Assim, o corpo cintilante torna-se um espelho de Lena, refletindo seus movimentos. Em silêncio, apenas acompanhada pela trilha sonora ruidosa, os corpos se comunicam pelos movimentos. A encenação, então, mantém a mesma proposta de criar uma artificialidade, agora pelos corpos que parecem dançar. Lena então explode o corpo estranho e tudo começar a pegar fogo. Como a alienígena em Sob a pele, aquilo que não reconhecemos como parte da natureza ou de uma lógica racional criada pelos seres humanos é repudiado e incendiado.

O filme utiliza diversos elementos de composição de imagem e som, como as cores, a iluminação, a trilha com ruídos não-diegéticos que dirigem nossa atenção mais para uma experiência contemplativa da imagem do que para 


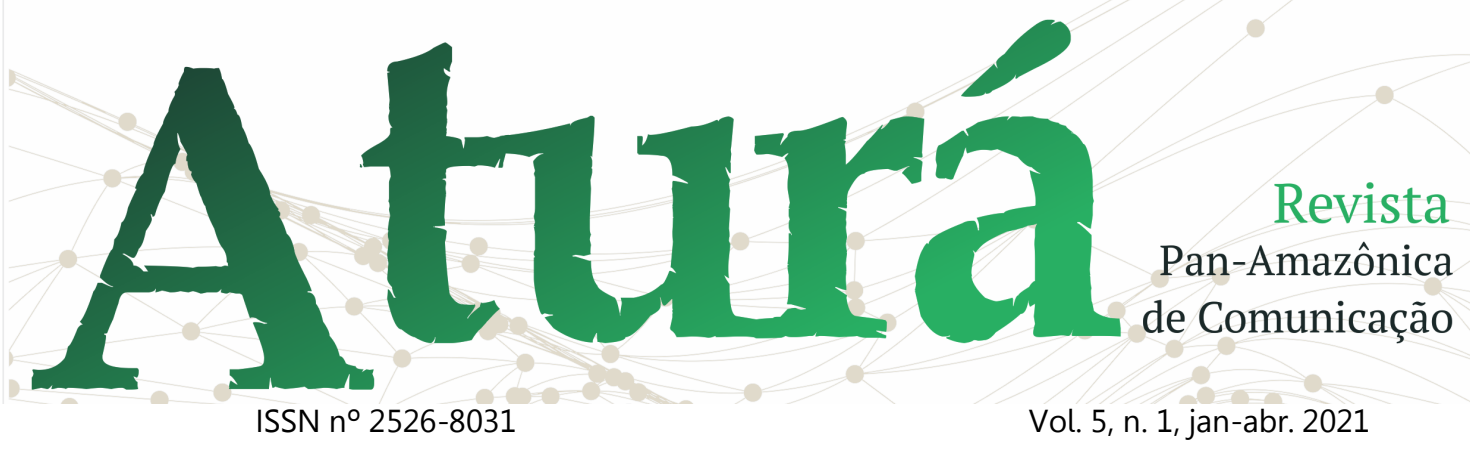

seus elementos discursivos. Da mesma forma como Lena contempla as estranhezas dentro do "Brilho", sem entender as causas e as consequências dos eventos na Área $\mathrm{X}$, a experiência espectatorial contempla a jornada de Lena, sem preocupar-se em entender os conflitos do filme e sem conseguir nomear o que vê ou suas razões de existir.

\section{Considerações finais}

O cinema de fluxo investe na valorização da dimensão sensorial da imagem e do som, indo em busca de uma experiência que ultrapasse os dados narrativos da história. Em um mundo globalizado e multicultural, os filmes de fluxo acompanham as mudanças de perspectiva no campo das relações entre o Cinema e a História, na esteira das transformações sociais, culturais, econômicas e políticas, e de seus reflexos nas sociedades humanas.

Os filmes de ficção científica que aderem à estética de fluxo, particularmente aqueles analisados neste 


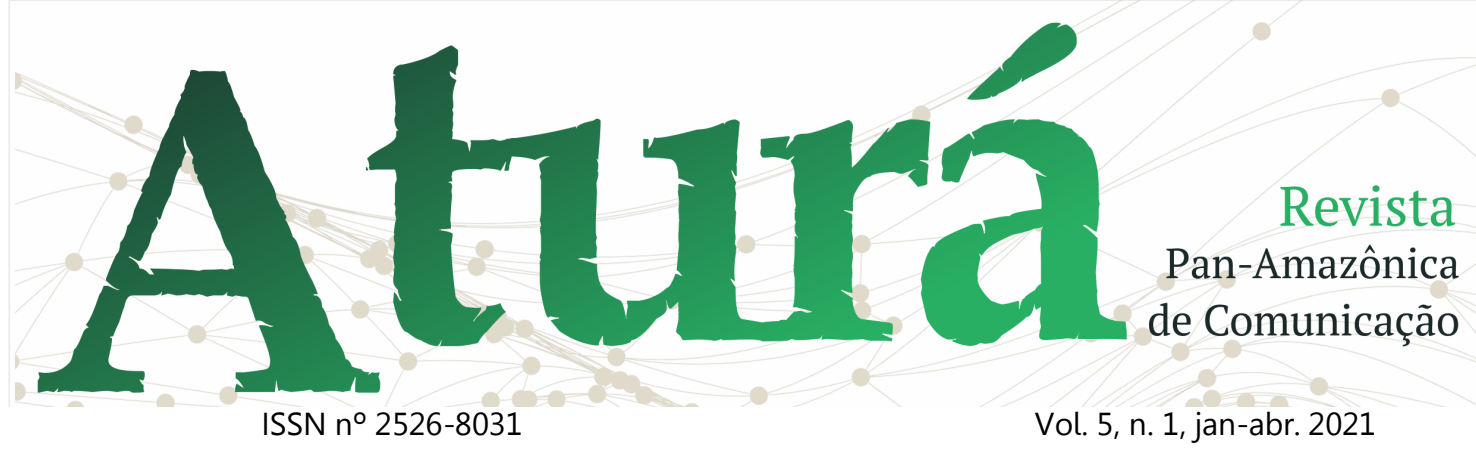

\section{Referências}

BERGALA, Alain. D'une certaine manière. Cahiers du Cinéma, n. 370, 1985, pp. 1115.

BOUQUET, Stéphane. Plan contre flux. Cahiers du Cinéma, n. 556, 2002.

HARTOG, François. Regimes de historicidade: presentismo e experiências do tempo. Belo horizonte: Autêntica Editora, 2015.

HOBSBAWM, Eric. Tempos fraturados: cultura e sociedade no século $X X$. São Paulo: Companhia das Letras, 2013.

MARTIN, Adrian. Turn the page: From mise en scene to dispositif. Screening the Past, v. 31. [Disponivel em https://www.screeningthepast.com/2011/ 07/turn-the-page-from-mise-en-sceneto-dispositif/, último acesso 20/10/2020]

OLIVEIRA JÚNIOR., Luiz Carlos. A mise en scène no cinema: Do clássico ao cinema de fluxo. São Paulo: Papirus, 2014.

VIERA JÚNIOR, Erly. Por uma exploração sensorial e afetiva do real: esboços sobre a dimensão háptica do cinema contemporâneo. In: Revista Fameco, Porto Alegre, v. 21, n. 3, p. 1219-1240, setembro-dezembro, 2014. 